\title{
In vitro and in vivo evaluation of sodium dodecyl sulfate (SDS) as an inactivator of caprine lentivirus (CLV) in colostrum and milk
}

\author{
[Avaliação in vitro $e$ in vivo do dodecil sulfato de sódio (SDS) como inativador do lentivírus
} caprino (LVC) em colostro e leite]

\author{
A.L.M. Sousa ${ }^{1}$, R.R. Pinheiro ${ }^{2}$, J.F. Araújo ${ }^{1}$, V.W.S. Santos $^{4}$, D.A.A. Azevedo ${ }^{1}$, R.M. Peixoto ${ }^{1}$, \\ V. Souza ${ }^{2}$, A. Andrioli ${ }^{2}$, E.M. Damasceno ${ }^{3}$, T.V.M. Dantas ${ }^{5}$, M.F.S. Teixeira ${ }^{1}$ \\ ${ }^{1}$ Universidade Estadual do Ceará - Fortaleza, CE \\ ${ }^{2}$ Embrapa Caprinos e Ovinos - Sobral, CE \\ ${ }^{3}$ Universidade Estadual Vale do Acaraú - Sobral, CE \\ ${ }^{4}$ Universidade Federal Rural do Semiárido - Mossoró, RN \\ ${ }^{5}$ Embrapa Tabuleiros Costeiros - Brasília, DF
}

\begin{abstract}
The aim of this study was to evaluate in vitro and in vivo the effect of sodium dodecyl sulfate (SDS) on the caprine lentivirus (CLV) in colostrum and milk. This was performed to develop a practical and efficient method of blocking the lactogenic transmission of the virus. In the in vitro experiment, colostrum and milk were treated with $0.25 \% ; 0.50 \%$ and $1 \%$ SDS. Then, somatic cells of colostrum and milk were submitted to co-culture with caprine synovial membrane cells (CSM). In the in vivo test, goats were fed with colostrum and milk provided from CLV-positive goats treated with SDS in the same concentrations used in the in vitro experiment. Animals were tested by nested polymerase chain reaction (nPCR) and Western blot (WB) assays. In the in vitro experiment, inhibitory activity against CLV without inactivation occurred in colostrum with all SDS concentrations. However, concentrations of 0.25 and $0.5 \%$ SDS presented only inhibitory activity against CLV in milk cells, and $1 \%$ concentration provided inactivation of the virus. In the in vivo tests, none of the three concentrations of SDS was effective in inactivating LVC in colostrum or goat milk, which was confirmed by seroconversion and presence of proviral DNA in animals afterwards.
\end{abstract}

Keywords: monocyte-phagocytic system, viral inactivation, surfactant, small ruminant lentiviruses

\section{RESUMO}

$O$ objetivo da pesquisa foi avaliar in vitro $e$ in vivo o efeito do dodecil sulfato de sódio (SDS) sobre o lentivírus caprino (LVC) no colostro e no leite, a fim de desenvolver um método prático e eficiente no bloqueio da via de transmissão lactogênica do vírus. No experimento in vitro, o colostro e o leite de cabras positivas foram tratados com SDS a 0,25\%, 0,50\% e 1,0\%. Em seguida, as células somáticas do colostro e do leite foram obtidas e direcionadas ao cocultivo com células de membrana sinovial caprina (MSC). No teste in vivo, os cabritos foram alimentados com colostro e leite providos de cabras positivas para LVC, tratados com SDS nas mesmas concentrações usadas no teste in vitro. Os animais foram acompanhados pelos testes de reação em cadeia da polimerase nested (nPCR) e western blot (WB). Nos resultados in vitro, no colostro, observou-se que, em todas as concentrações de SDS, ocorreu uma atividade inibitória contra o LVC, sem a inativação. Em relação às células do leite, o SDS apresentou, nas concentrações de 0,25 e 0,5\%, atividade inibitória contra o LVC, e na concentração de 1\%, houve inativação viral. Nos testes in vivo, as três concentrações de SDS testadas não foram efetivas na inativação do LVC no colostro e no leite caprino, o que se comprovou pela soroconversão e pela presença de DNA proviral nos animais.

Palavras-chave: sistema monociticofagocitário, inativação viral, surfactante, lentiviroses de pequenos ruminantes

Recebido em 11 de novembro de 2016

Aceito em 8 de maio de 2018

E-mail: analidiams10@yahoo.com.br 


\section{INTRODUCTION}

Small ruminant lentiviruses (SRLVs) are diseases caused by viruses of the Retroviridae family, genus Lentivirus. These pathogens include ovine lentivirus (OLV) and caprine lentivirus (CLV) (Pisoni et al., 2005). SRLVs cause significant economic losses in goat production (Carneiro, 2011) and clinically cause interstitial pneumonia, arthritis, mastitis, and progressive emaciation, in addition to neurologic conditions in goat kids (Callado et al., 2001).

Lactogenic transmission in either colostrum or milk is a natural model of infection recognized in lentiviruses in general. This form guarantees viral dissemination between generations and persistence of the pathogen in the flock in a population level. In addition, this aspect has a fundamental role in the biology of these viruses, considering that it is one of the main forms of transmission (Pisoni et al., 2010). According to Herrmann-Hoesing et al. (2007), animals are exposed to infection by the ingestion of colostrum contaminated with free viral particles and proviruses within monocytes and macrophages, which are then absorbed in the gastrointestinal tract.

Among the blockade techniques of the virus in lactogenic transmission, thermization can be performed in colostrum, transition milk and common milk. Colostrum, for instance, after collection from does soon after giving birth, may be placed in plastic bottles which are sealed and submitted to water bath at $56^{\circ} \mathrm{C}$ for an hour. Then, bottles are removed and cooled to room temperature, which may then be stocked at $-20^{\circ} \mathrm{C}$ until milk feeding (Peretz et al., 1993; Andrade, 2008). However, this method may present costs, considering the necessary equipment, such as water bath or heater, and technical labor. Therefore, low cost and practical alternatives that effectively block SRLVs transmission in colostrum and milk are necessary for goat farmers.

Some studies correlating the use of chemical additives in milk with an inhibitory activity of microorganisms have been performed (Muller e Syhre, 1975; Krebs et al., 1999; Urdaneta et al., 2005). Among these, sodium dodecyl sulfate (SDS), a surfactant with cytolytic properties, presents a possible antiviral activity in cell cultures of HIV-1 (Human immunodeficiency virus type 1), HSV (Herpesvirus) and HPV (Papillomavirus) (Piret et al., 2002). Krebs et al. (1999) and Urdaneta et al. (2005) demonstrated that $0.1 \%$ SDS may be effective in inactivating HIV-1 in milk and reported that this concentration is in accordance with safe limits for child consumption. In addition, other studies indicate that $1 \%$ SDS in colostrum is an effective biocide and there is no interference in passive transference of immunity or health problems in goat kids (Morales-De La Nuez et al., 2011). Therefore, this study aimed to evaluate in vitro and in vivo the use of sodium dodecyl sulfate (SDS) in colostrum and milk positive for the caprine lentivirus (CLV) in order to develop a practical and efficient method of blocking the lactogenic transmission of the virus.

\section{MATERIAL AND METHODS}

This study was approved by the Ethics Committee for the Use of Animals of the Embrapa Goats and Sheep with the protocol number 012/2014.

The experiment was performed in the same location and divided in two phases (in vitro and in vivo). In the first phase, colostrum of five adult goat nannies seropositive for CLV, which were tested with Western blot technique, was collected in sterile tubes after giving birth. Approximately $25 \mathrm{~mL}$ of colostrum was collected from each animal and samples were combined in a pool, which was subdivided in 12 aliquots of $10 \mathrm{~mL}$ each. Milk collection was performed in the same animals after 30 days following the same methodology.

SDS (CEQuímica®, Brasil) treatment was performed adding the compound to colostrum and milk samples in the concentrations of $0.25 \%$, $0.5 \%$ and $1 \%$ in triplicate for $15 \mathrm{~min}$. Control treatments were used in colostrum and milk without adding SDS. Then, samples were centrifuged at $3,000 \mathrm{~g}$ for $15 \mathrm{~min}$ at $4^{\circ} \mathrm{C}$. Somatic cells were obtained following the methodology of Karanikolaou et al. (2005).

In order to perform co-culture with caprine synovial membrane cells (CSM), biological samples from SDS treatment step in colostrum and milk were washed with $1000 \mu \mathrm{L}$ of $1 \mathrm{X}$ PBS (phosphate-buffered saline: $8 \mathrm{~g} \mathrm{NaCl} ; 0.2 \mathrm{~g} \mathrm{KCl}$; 
$0.2 \mathrm{~g} \mathrm{KH}_{2} \mathrm{PO}_{4} ; 1.15 \mathrm{~g} \mathrm{Na}_{2} \mathrm{HPO}_{4}$ and $1000 \mathrm{~mL}$ of $\mathrm{H}_{2} \mathrm{O}$ q.s.p.; components: Sigma-Aldrich ${ }^{\circledR}$, EUA) for removing SDS. Then, $1000 \mu \mathrm{L}$ of minimal essential medium (MEM - Gibco®, EUA), treated with 2\% amphotericin B (SigmaAldrich $\circledast$, EUA), $3 \%$ penicillin and streptomycin (P/S - Gibco®, EUA), $1 \%$ gentamycin (SigmaAldrich ${ }^{\circledR}$, EUA) and $10 \%$ fetal bovine serum (FBS - Gibco®, EUA) was added. Then, aliquots of $100 \mu \mathrm{L}$ of samples were distributed in 24 well plates in eight repetitions, in which $1900 \mu \mathrm{L}$ of MEM treated with 5\% of FBS was added. A total of 16 control wells were used throughout the culture period. In half, only CSM cells were added as negative control. In the other half of wells, CSM cells infected with standard sample of CLV (CAEV-Cork) with an initial titer of $10^{4.8} \mathrm{TCID} 50 / \mathrm{mL}$ were added as positive control. Plates were incubated in $5 \% \mathrm{CO}_{2}$ at $37^{\circ} \mathrm{C}$ for $24 \mathrm{~h}$. Then, CSM cells were added in eighth passage in the concentration $2.0 \times 10^{5} \mathrm{cells} / \mu \mathrm{L}$, following incubation in the same previous conditions. In every seven days, media were replaced and cellular trypsinization was performed, and a total duration of 63 days of culture. Supernatants were collected and separated per treatment to be submitted to nested polymerase chain reaction (nPCR). Following culture, four wells of each treatment were stained with violet crystal $(0.1 \%)$ and the remaining was submitted to trypsinization to collect cellular material.

Proviral DNA extraction of cellular supernatant from co-culture was performed according to the methodology by Feitosa et al. (2011) and nPCR was performed according to Barlough et al. (1994).

In phase two of experimentation (in vivo), SDS was tested in 31 goat kids, male, born of females negative for CLV by WB and nPCR. Three experimental groups were formed according to the concentrations of SDS, containing seven goat kids each. In addition, two control groups (positive and negative) were formed with five animals. Goat kids were immediately separated after birth, weighted, and submitted to the same diagnostic tests.

SDS was diluted from a standard concentration (SC) to $10 \%$ using $100 \mathrm{~g}$ SDS for every $1000 \mathrm{~mL}$ of sterile Milli-Q water. To form the concentrations of $0.25 \%, 0.5 \%$ and $1 \%$, the volumes $25 \mathrm{~mL}, 50 \mathrm{~mL}$ and $100 \mathrm{~mL}$ of $\mathrm{SC}$ were used, respectively, for every liter of caprine colostrum or milk used in feeding the animals of each experimental group.

Inoculum was prepared with SDS using colostrum and milk collected daily from positive nannie goats. Before any treatment, aliquot $(10 \mathrm{~mL})$ of colostrum and milk were collected for nPCR test to confirm the presence of CLV in the samples. Then, colostrum and milk were treated with SDS in the previous concentrations for $15 \mathrm{~min}$ and administered to the goat kids. Negative control animals received colostrum and milk treated thermally $\left(56^{\circ} \mathrm{C}\right.$ for $\left.60 \mathrm{~min}\right)$ and positive control received colostrum and milk from infected goats. Treatments were administered to animals for six days. Then, animals received thermally treated milk until weaning.

Along with milking, experimental monitoring was performed, in which blood collection was performed for diagnostic tests in days $0,7,15,30$ and every month for a semester. Blood was collected with venipuncture of jugular vein. Blood serums and leucocytes were maintained in microtubes (Eppendorf®), EUA) and frozen at $20^{\circ} \mathrm{C}$ until WB was performed, which followed methodology by Pinheiro et al. (2011), and nPCR.

\section{RESULTS AND DISCUSSION}

Viral cytopathic effects were investigated in vitro evaluation with co-culture of CSM and somatic cells of colostrum and goat milk treated with SDS at $0.25 \%, 0.5 \%$ and $1 \%$ after 63 days of culture (Table 1). Colostrum treatments of $0.25 \%$ and $0.5 \%$ SDS revealed a gradual decrease in the presence of syncytium and cell destruction. The concentration of $1 \%$ SDS did not cause cytopathic effects, which is an indication of CLV infection. In milk, $0.25 \%$ SDS treatment reduced the formation of syncytium and cell destruction. The concentrations of $0.5 \%$ and $1 \%$ did not produce cytopathic effects. 
Table 1. Levels of cytopathic effects in CSM cells after co-culture with somatic cells of colostrum and milk treated with SDS

\begin{tabular}{|c|c|c|c|c|c|c|c|c|c|c|c|c|}
\hline \multirow{3}{*}{$\begin{array}{l}\text { Cytopathic } \\
\text { effects }\end{array}$} & \multicolumn{12}{|c|}{ SDS Treatments } \\
\hline & \multicolumn{6}{|c|}{ Colostrum } & \multicolumn{6}{|c|}{ Milk } \\
\hline & $\mathrm{C}^{-}$ & $\mathrm{C}^{+}$ & $\mathrm{N} / \mathrm{SDS}$ & $0.25 \%$ & $0.5 \%$ & $1 \%$ & $\mathrm{C}^{-}$ & $\mathrm{C}^{+}$ & N/SDS & $0.25 \%$ & $0.5 \%$ & $1 \%$ \\
\hline Syncytium & - & +++ & ++ & + & - & - & - & +++ & ++ & $+(+)$ & - & - \\
\hline $\begin{array}{c}\text { Cellular } \\
\text { Destruction }\end{array}$ & - & +++ & + & $(+)$ & $(+)$ & - & - & +++ & ++ & $+(+)$ & - & - \\
\hline
\end{tabular}

$\mathrm{C}^{-}$: negative control; $\mathrm{C}^{+}$: positive control; N/SDS: no SDS. -: no cytopathic effect; $(+)$: very light cytopathic effect, + : light effect; $+(+)$ : light to moderate effect; ++ : moderate effect; +++: intense effect.

Figure 1 demonstrates viral cytopathic effects caused by CLV in CSM cells from co-culture with somatic cells from caprine colostrum and milk treated with SDS. The cytopathic effects of multi-nucleated cells and cell destruction were observed in cultures without the addition of SDS (Figure 1A to $1 \mathrm{~J}$ ).

A gradual reduction of cytopathic effect was observed with the progression of the experiment according to the SDS concentration of treatments. In addition, $1 \%$ SDS concentrations in colostrum did not present characteristics of viral infection (Figure 1F). In milk, this decrease was observed in SDS concentrations of $0.5 \%$ and $1 \%$ (Figure $1 \mathrm{~K}$ and $1 \mathrm{~L}$ ). In both co-cultures, cells from mammary glands characterized by rounded forms and increased nuclei in comparison to CSM were observed (Figure 1E, 1F).

Viral cytopathic effects were more clearly observed in samples of colostrum in comparison to milk. This difference may be related to the defense cells (monocytes and macrophages) and lipid molecules, which are found in greater rates in colostrum. These characteristics decrease SDS efficiency due to the superior proportions of fat in comparison to surfactant, causing a possible reduction in processes of cell suffering and lysis (Partearroyo et al., 1990; Kalmanzon et al., 1992). In this context, monocytes/macrophages when are not destroyed may carry the virus in a cellular and flock level (Herrmann-Hoesing et al., 2007).

Table 2 present analyses of cell suspension and supernatant with nPCR test in 63 days of coculture. Colostrum samples presented positive results at least once in tests, independent of SDS treatment. Milk samples presented positive results in reactions of SDS treatments $0.25 \%$ and $0.5 \%$. However, $1 \%$ SDS concentration did not present positive results in any of the samples submitted to nPCR test throughout the experiment.

Data found in this study demonstrated that SDS presented inhibitory activity against CLV in colostrum, considering the decrease in cytopathic effects as concentrations increased. However, a complete viral inactivation was not possible. In milk, SDS presented partial inhibitory activity against CLV in $0.25 \%$ and $0.5 \%$ concentrations, considering the decrease in cytopathic effects as concentrations of the surfactant were increased. However, 1\% SDS presented a probable viral inactivation of CLV in culture, considering the absence of cells with infectious characteristics and negative nPCR results.

Comparing the viral activity of SDS in CLV and data found in literature with HIV-1 revealed that SDS concentrations needed for a significant result of CLV inactivation were ten times higher than what Urdaneta et al. (2005) used. These authors evaluated samples in a rapid in vitro system (MAGI - Multinuclear Activation of Galactosidase Indicator), which quantifies viral infectiveness after microbiocide treatment. They found that SDS concentrations of 0.1 and $0.5 \%$ for $10 \mathrm{~min}$ in HeLa cultures were sufficient to cause full inhibition of viral infection caused by HIV-1 in milk. Similar findings were observed used in studies performed by Krebs et al. (1999) with $0.025 \%$ and $0.05 \%$ SDS in HIV-1, which are 20 and 40 times lower than $1 \%$ concentration used in this study. 


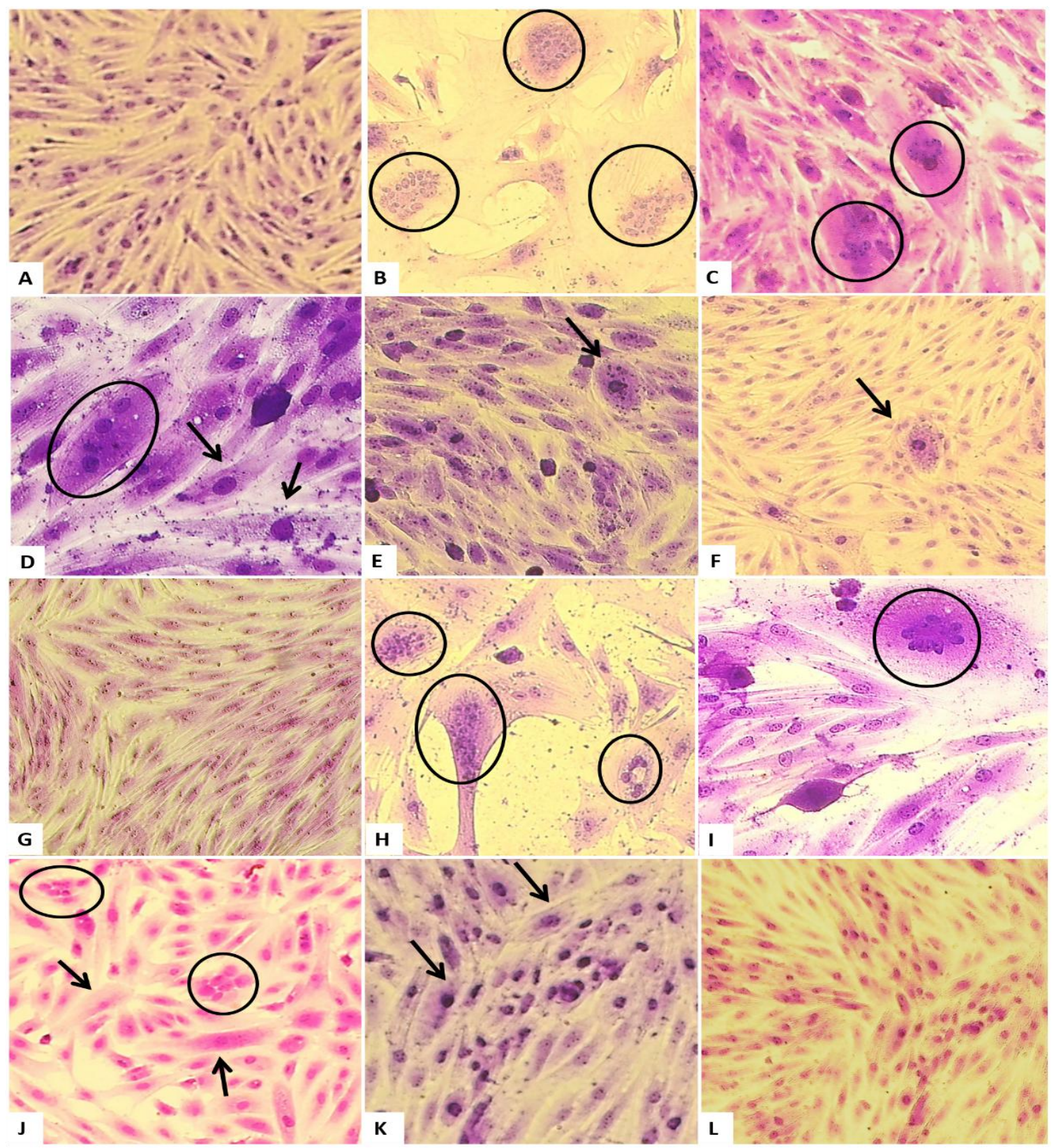

Figure 1. Co-culture of CSM and somatic cells in colostrum and milk. A and G: negative control of CSM cells (100x magnification). B and $\mathrm{H}$ : positive control of culture (100x magnification); C and I: control treatment (N/SDS) with colostrum and milk cells, respectively, with cytopathic effects (200x magnification). D, E and F: SDS treatment at $0.25 \%, 0.5 \%$ and $1 \%$ in colostrum, respectively. D: $0.25 \%$ SDS with presence of syncytium (circle) and cells visually increased in size (magnification 200x). E: SDS treatment at $0.5 \%$ with presence of cells (arrow) visually increased in size and rounded (magnification 200x). F: SDS treatment at $1 \%$ without the presence of cytopathic effects and only some cells (arrow) with a differentiated morphology in comparison to the others in colostrum (magnification 100x). J, K and L: SDS treatment at $0.25 \%, 0.5 \%$ and $1 \%$ in milk, respectively; J: $0.25 \%$ SDS treatment with presence of syncytium (circle) and cells visually increased in size (200x magnification); K: 0.5\% SDS treatment with presence of cells (arrows) visually increased in size (200x magnification); L: 1\% SDS treatment without the presence of cytopathic effect (100x magnification). 
Table 2. Results of nPCR in supernatant samples of CSM and somatic cells co-culture from colostrum and milk

\begin{tabular}{ccccccc} 
SDS & \multicolumn{5}{c}{ Colostrum } \\
\cline { 2 - 7 } $\begin{array}{c}\text { Concentrations } \\
(\%)\end{array}$ & $21 \mathrm{~d}^{*}$ & $42 \mathrm{~d}$ & $63 \mathrm{~d}$ & $21 \mathrm{~d}$ & $42 \mathrm{~d}$ & $63 \mathrm{~d}$ \\
\hline 0.25 & + & + & + & + & + & + \\
0.5 & + & + & - & + & + & + \\
1 & + & - & + & - & - & - \\
\hline
\end{tabular}

*: days of culture

A greater resistance of SRLV in comparison to HIV was also observed by Thormar et al. (1995), which used several viral inhibitors, among these: plant derived lectins (LOA, GNA, NPA, CA, GlcNAc, UDA, Gal-4, GalNAc, SNA-II, BPA, IRA, SBA, Neu5Ac, Gal / GalNAc), TIBO-RT (tetrahydroimidazo-[4,5,1-jk][1,4]-

benzodiazepin-2-(1H)-one, reverse transcriptase inhibitor) and AZT (3'-Azido-2',3'dideoxythymidine). These authors verified that concentrations 12 to 40 times higher of lectin,
200 to 300 times higher of TIBO-RT and 5 to 10 times higher of AZT were necessary to cause a full inactivation of Maedi-Visna virus (MVV) in comparison to concentrations used for HIV.

In the second experimental phase (in vivo), molecular (nPCR) and serological (WB) followups were performed in experimental animals, which were fed with colostrum and milk of infected goat nannies treated with SDS at $0.25 \%$, $0.5 \%$ and $1 \%$ (Table 3 ).

Table 3. Individual monitoring with nPCR and WB of experimental animals

\begin{tabular}{|c|c|c|c|c|c|c|c|c|c|c|c|c|c|c|c|}
\hline \multirow[b]{2}{*}{ Groups } & \multirow[b]{2}{*}{ Animal } & \multicolumn{2}{|c|}{$0 \mathrm{~d}$} & \multirow[t]{2}{*}{$7 d$} & \multirow{2}{*}{$15 \mathrm{~d}$} & \multirow{2}{*}{$\begin{array}{l}30 \mathrm{~d} \\
\mathrm{R} \\
\end{array}$} & \multirow[t]{2}{*}{$60 d$} & \multicolumn{2}{|c|}{$90 \mathrm{~d}$} & \multicolumn{2}{|c|}{$120 \mathrm{~d}$} & \multicolumn{2}{|c|}{$150 \mathrm{~d}$} & \multicolumn{2}{|c|}{$180 \mathrm{~d}$} \\
\hline & & ${ }_{n} \mathrm{PCR}$ & WB & & & & & ${ }_{n} \mathrm{PCR}$ & WB & ${ }_{\mathrm{n}} \mathrm{PCR}$ & WB & ${ }_{n} \mathrm{PCR}$ & WB & ${ }_{n} \mathrm{PCR}$ & WB \\
\hline \multirow{5}{*}{ Cont.(-) } & A & - & - & - & - & - & - & - & - & - & - & - & - & - & - \\
\hline & B & - & - & - & - & - & - & - & - & - & - & - & - & - & - \\
\hline & C & - & - & - & - & - & - & - & - & - & - & - & - & - & - \\
\hline & $\mathrm{D}$ & - & - & - & - & - & - & - & - & - & - & - & - & - & - \\
\hline & $\mathrm{E}$ & - & - & - & - & - & - & - & - & - & - & - & - & - & - \\
\hline \multirow{5}{*}{ Cont.(+) } & F & + & - & + & + & + & - & - & + & - & + & + & + & + & + \\
\hline & $\mathrm{G}$ & - & - & - & - & + & + & - & - & - & - & - & - & + & - \\
\hline & $\mathrm{H}$ & - & - & - & - & - & - & - & + & - & + & - & + & + & + \\
\hline & I & - & - & - & + & + & - & - & + & - & - & - & + & + & + \\
\hline & $\mathrm{J}$ & - & - & - & - & - & + & - & + & - & + & - & + & - & + \\
\hline \multirow{7}{*}{$\begin{array}{c}\text { G1 } \\
(0.25 \%)\end{array}$} & $\mathrm{K}$ & - & - & - & - & - & - & - & + & - & + & - & + & - & + \\
\hline & $\mathrm{L}$ & - & - & + & + & + & - & + & - & * & & & & & \\
\hline & M & - & - & - & - & - & - & - & - & - & - & + & - & + & - \\
\hline & $\mathrm{N}$ & - & - & - & + & - & - & - & + & - & - & - & + & - & + \\
\hline & $\mathrm{O}$ & - & - & - & - & + & - & - & - & - & - & + & - & + & - \\
\hline & $\mathrm{P}$ & - & - & - & + & - & - & - & - & - & + & + & - & + & - \\
\hline & Q & - & + & & \# & & & & & & & & & & \\
\hline \multirow{7}{*}{$\begin{array}{c}\mathrm{G} 2 \\
(0.5 \%)\end{array}$} & $\mathrm{R}$ & - & - & - & - & - & - & - & + & - & - & - & - & + & - \\
\hline & $S$ & - & - & + & - & - & - & + & - & & & & & & \\
\hline & $\mathrm{T}$ & - & - & - & - & + & - & - & + & - & + & - & + & + & + \\
\hline & U & - & - & - & + & - & - & - & - & - & - & + & - & - & - \\
\hline & V & - & - & + & - & - & + & - & - & & . & & & & \\
\hline & W & - & - & - & - & - & + & + & + & - & + & - & + & - & + \\
\hline & $X$ & - & - & - & - & - & - & - & - & - & - & + & - & - & - \\
\hline \multirow{3}{*}{$\begin{array}{l}\text { G3 } \\
(1 \%)\end{array}$} & $\mathrm{Y}$ & - & - & - & - & - & - & - & - & - & - & + & - & + & - \\
\hline & $\mathrm{Z}$ & - & - & - & - & - & - & - & + & - & - & - & + & + & + \\
\hline & $\mathrm{A} 1$ & - & - & - & - & - & - & - & + & - & - & - & - & + & - \\
\hline
\end{tabular}

+: positive diagnostic, - : negative diagnostic, $*$ : animals that died before collection of 120 days (suggestive of clostridiosis), \#: animal eliminated from group due to positive result in $0 \mathrm{~h}$ in WB test. 
Positive results were found soon in the second collection (7 days) for nPCR after experimentation in G1 and G2. In collections performed after 180 days, $60 \%$ (3/5) of animals in G1 and $40 \%(2 / 5)$ of G2 were positive in nPCR. Animals of G3 were positive for CAEV only in collection performed at 150 days, when one animal (33\%) was positive. However, at 180 days, $100 \%(3 / 3)$ of animals were positive. Data found in this study demonstrated that SDS concentrations tested in caprine milk and colostrum did not promote in vivo inactivation of the lentivirus, exposing animals to infection.

At 90 days of evaluation, antibodies for CLV were identified in WB test of all groups that received colostrum/milk (G1- 33.3\%; G2 42.8\%; G3 - 66.7\%; and positive control group $80 \%$ ), confirming the infection and activation of immune system. In addition, animals from these groups were also positive in all collection thereafter (120 days, 150 days, and 180 days). Antibodies for CLV found until 70 days of life detected by WB are very likely to have been originated from colostrum (Souza et al., 2015). Antibodies were detected after 120 days of life and proviral DNA after seven days of experimentation, which indicates that SDS concentrations were not effective in viral inactivation, confirming results obtained with molecular and serological diagnostic tests.

Despite the report by Piret et al. (2002), which demonstrates that SDS is a potent inhibitor of infectiveness of enveloped and non-enveloped viruses due to protein denaturation properties, the in vivo study here reported did not present CLV inactivation. In addition, this data contradicts the in vitro results by Urdaneta $e t$ al. (2005), which assessed infectiveness level of HIV. According to these authors, concentrations and time of action of SDS were sufficient to inhibit in full the viral infection index of HIV-1 in milk. This study does not corroborate with Krebs et al. (1999), which identified inhibition of HIV-1 by SDS concentrations of $0.0025 \%$ to $0.05 \%$.

In addition to evaluating the SDS effect as viral inactivator, the second experimental phase (in vivo) allowed the assessment of receptiveness of goat kids to treated colostrum and milk. During milk feeding, animals from G1 did not present clinical alterations, demonstrating a good receptiveness in consuming colostrum and milk treated with SDS at $0.25 \%$. Animals from G2 and G3 presented good acceptance of colostrum treated with SDS at $0.5 \%$ and $1 \%$, respectively, without clinical signs. However, during the milkfeeding period, both groups presented rejection to treated milk in the same concentrations as SDS. To improve palatability, $2 \mathrm{~g}$ of strawberry flavored Nesquik (Nestle®) was added to every $200 \mathrm{~mL}$ of milk. After $24 \mathrm{~h}$ of treatment, all animals from G2 group (7/7) presented light diarrhea. However, these animals remained in the experiment until the period of six days administering milk was ended. In G3 group, after $24 \mathrm{~h}$ of ingestion of milk treated with SDS at $1 \%$, $57.1 \%(4 / 7)$ of animals died and the remaining presented intense diarrhea and apathy. Therefore, treatment was suspended, and animals were maintained and monitored until the end of the experiment.

Hartmann et al. (2006) described a method of removing SDS with a commercial resin, which is based in the ion-exchange chromatography. This is considered an efficient method for removing SDS, considering that protein recovery of 4 out of 5 samples of human milk treated with $1 \%$ SDS was $100 \%$. However, this method would not be applicable or profitable for goat farmers, considering the equipment, reagents and specialized labor necessary to execute. In this sense, SDS was not removed from milk or colostrum provided for goat kids in the second experimental phase.

These adverse effects that occurred in G2 and G3 probably occurred due to the lytic activity of SDS, which was not completely emulsified to lipids found in milk, causing possible lesions in gastrointestinal epithelial cells. SDS in direct contact with cells may cause permeability alterations in plasma membrane, which is the target structure for this substance (Benoit $e t$ al., 1987; Partearroyo et al., 1990).

According to Morales-De La Nuez et al. (2011), SDS treatment at $1 \%$ in caprine colostrum promoted a reduction in bacterial load and lower destruction of immunoglobulin $\mathrm{G}$ ( $\operatorname{IgG}$ ) in comparison to what is observed in pasteurization. In addition, these authors reported that goat kids fed with $1 \%$ SDS in colostrum did not present pathological effects of alterations in passive immune transference. 
Kimura and Yoshida (1982) observed the reduction of enzymatic activities in pharmacological studies after administration of SDS at $0.25 \%$ in diet of mice. During experimentation, diarrhea, exfoliation of gastrointestinal membrane and malnutrition were observed in animals.

Data observed in this study with the sole administration of colostrum treated with SDS corroborate with Morales-De La Nuez et al. (2011) in health status of the animals. However, SDS may cause diverse effects when administered in diet, corroborating with data by Kimura e Yoshida (1982).

\section{CONCLUSIONS}

The in vitro study promoted inhibition of the caprine lentivirus in milk only in the $1 \%$ concentration of SDS. In the in vivo evaluation, SDS in colostrum/milk in none of the tested concentrations promoted inactivation of the caprine lentivirus. In addition, gastrointestinal complications occurred, such as profuse diarrhea. However, more studies are necessary in the chemical inactivation of virus to elucidate the activity of SDS in small ruminant lentiviruses. Considering the promising in vitro results found in this study, more studies involving the action of this compound in colostrum and milk should be performed.

\section{REFERENCES}

ANDRADE, M.L.R. Avaliação da dinâmica de absorção do colostro em caprinos das raças saanen e moxotó explorados no semi-árido cearense. 2008. 60f. Dissertação (Mestrado Em Zootecnia) - Universidade Estadual Vale Do Acaraú, Sobral, CE.

BARLOUGH, J.; EAST, N.; ROWE, J.D. et al. Double-nested polymerase chain reaction for detection of caprine arthritis-encephalitis virus proviral DNA in blood, milk and tissues of infected goats. J. Virol. Methods, v.50, p.101114, 1994.

BENOIT, J.; CORMIER, M.; WEPIERRE, J. Effect of proteins on the assessment of surfactant cytotoxicity by an in vitro test: possible correlation with in vivo data. Toxicol. In Vitro, v.1, p.91-96, 1987.
CALLADO, A.K.C.; CASTRO, R.S.; TEIXEIRA, M.F.S. Lentivírus de pequenos ruminantes (LVC e Maedi-Visna): revisão e perspectivas. Pesqui. Agropecu. Bras., v.21, p.87-97, 2001

CARNEIRO, F.F.D. Perdas econômicas decorrentes da artrite encefalite caprina. 2011. 97f. Dissertação (Mestrado em Zootecnia) Universidade Estadual Vale do Acaraú, Sobral, CE.

FEITOSA, A.L.V.L.; TEIXEIRA, M.F.S.; PINHEIRO, R.R. et al. Primeiro isolamento de lentivírus de pequenos ruminantes em caprino naturalmente infectado em rebanho do Rio Grande do Norte, Brasil. Arq. Inst. Biol., v.78, p.501-505, 2011.

HARTMANN, S.U.; WIGDAHL, B.; NEELY, E.B. et al. Biochemical analysis of human milk treated with sodium dodecyl sulfate, an alkyl sulfate microbicide that inactivates human immunodeficiency virus type 1. J. Hum. Lact., v.22, p.61-74, 2006.

HERRMANN-HOESING, L.M.; PALMER, G.H.; KNOWLES, D.P. Evidence of proviral clearance following postpartum transmission of an ovine lentivirus. Virology, v.362, p.226-234, 2007.

KALMANZON, E.; ZLOTKIN, E.; COHEN, R.; BARENHOLZ, Y. Liposomes as a model for the study of the mechanism of fish toxicity of sodium dodecyl sulfate in sea water. Biochem. Biophys. Acta, v.1103, p.148-156, 1992.

KARANIKOLAOU, K.; ANGELOPOULOU, K.; PAPANASTASOPOULOU, M. et al. Detection of small ruminant lentiviruses by nPCR and serology tests in field samples of animals from Greece. Small Ruminant Res., v.58, p.181-187, 2005.

KIMURA, T.; YOSHIDA, A. Toxicity of detergent feeding and effect of the concurrent feeding of dietary fiber in rats. Nutr. Rep. Int., v.26, p.271-279, 1982.

KREBS, F.C.; MILLER, S.R.; MALAMUD, D. et al. Inactivation of human immunodeficiency virus type 1 by nonoxynol-9, C31G, or an alkyl sulfate, sodium dodecyl sulfate. Antivir. Res., v.43, p.157-173, 1999. 
MORALES-DE LANUEZ, A.; MORENOINDIAS, I.; SANCHEZ-MACIAS, D. et al. Sodium dodecyl sulfate reduces bacterial contamination in goat colostrum without negative effects on immune passive transfer in goat kids. J. Dairy Sci., v.94, p.410-415, 2011.

MULLER, L. D.; SYHRE, D.R. Influence of chemicals and bacterial cultures on preservation of colostrum. J. Dairy Sci., v.58, p.957-961, 1975 .

PARTEARROYO, M.A.; OSTOLAZA, H.; GONI, F.M.; BARBERA-GUILLEM, E. Surfactant-induced cell toxicity and cell lysis. Biochem. Pharmacol., v.40, p.1323-1328, 1990.

PERETZ, G.; ASSO, J.; DEVILLECHAISE, P. Le CAEV: revue des connaissances actuelles et conséquences pratiques. Rev. Méd. Vét. v.144, p.93-98, 1993.

PINHEIRO, R.R.; BRITO, R.L.L.; RODRIGUES, A.S. et al. Protocolo de immunoblotting para diagnóstico da artrite encefalite caprina. Sobral: Embrapa, 2011. 4p. (Comunicado Técnico, 122).

PIRET, J.; DÉSORMEAUX A.; BERGERON, M.G. Sodium lauryl sulfate, a microbicide effective against enveloped and nonenveloped viruses. Curr. Drug Targets, v.3, p.17-30, 2002.
PISONI, G.; BERTONI, G.; MANAROLLA, G. et al. Genetic analysis of small ruminant lentiviruses following lactogenic transmission. Virology, v.407, p.91-99, 2010.

PISONI, G.; QUASSO, A.; MORONI, P. Phylogenetic analysis of small-ruminant lentivirus subtype B1 in mixed flocks: Evidence for natural transmission from goats to sheep. Virology, v.339, p.147-152, 2005.

SOUZA, T.S.; PINHEIRO R.R.; COSTA, J.N. et al. Interspecific transmission of small ruminant lentiviruses from goats to sheep. Braz. J. Microbiol., v.46, p.867-874, 2015.

THORMAR, H.; BALZARINI, J.; DEBYSER, Z. et al. Inhibition of visna virus replication and cytopathic effect in sheep choroid plexus cell cultures by selected anti-HIV agentes. Antivir. Res., v.27, p.49-57, 1995.

URDANETA, S.; WIGDAHL, B.; NEELY, E.B. et al. Inactivation of HIV-1 in breast milk by treatment with the alkyl sulfate microbicide sodium dodecyl sulfate (SDS). Retrovirology, v.2, p.28, 2005. 